\title{
Onko yliopistolla syytä juhlaan?
}

Tunnustan kuuluvani niihin, joita valmistautuminen Suomen yliopistolaitoksen juhlavuoden juhlintaan alkoi tympiä jo vuosi sitten. Samoihin aikoihin lakkasin lukemasta Päiviö Tommilan kirjoituksia. Valmistelut loivat vahvan vaikutelman, että tapahtumalla ei ole mitään yhteyttä yrityksiin hahmottaa, saatikka ratkaista, suomalaista yliopistolaitosta koskevia mitä polttavimpia ongelmia. Odotukset ovat osoittautuneet valitettavan todenmukaisiksi.

Suomalaisen yliopiston perustava tapahtumisen taso on se, mitä yliopistoväki . tekee. Näkökulmani tähän on subjektiivinen, kuten väistämättä jokaisen, mutta oletan omassa toimintapiirissäni (Helsingin yliopisto, Eläintieteen laitos) harjoitettujen toimintojen olevan muunnelmia yleisistä teemoista.

On se aika vuodesta, jolloin opettajat, $\mathrm{mm}$. dosentit, tekevät tulevan lukuvuoden opetusilmoituksensa. Ilmoituksen tekeminen on vitsikästä kun sitä tehdessään tietää, että opetus ei toteudu. Eläintieteen laitoksen opetusmäärärahat ovat supistuneet aiemmasta $29 \%$. Tämä ei suinkaan ole vain dosenttien henkilökohtainen ongelma vaan merkitsee sitä, että myös osa pakollisista kursseista - joita on kautta aikojen annettu dosenttiopetuksen turvin — jää tästedes pitämättä. Dosenttiopetuksen loppuminen on rinnasteista tuntiopetuksen supistumiselle muualla.

Myös opiskelijat tietävät, että ilmoitetuista kursseista huomattava osa jää pitämättä. Eläintieteessä, kuten lukuisissa muissakin aineissa, on ensi lukuvuonna oleva vaikea saada kokoon opintotuen jatkumiseen vaadittavia suoritusmääriä, koska opetusta ei anneta riittävästi. Jatkotutkintoihin vaadittavien opintojen suorittaminen on oleva erityisen hankalaa, koska erityiskurssit putoavat ensimmäisinä ohjelmasta. Laitoksen opettajien kannalta on onni, että henkilökohtaiseen opinto-ohjaukseen ei ole edellytyksiä: minkä neuvon opiskelijoille voisi antaa? Kehottaisiko heitä harrastamaan ajankulukseen kieliä?

Jatko-opiskelijoiden asema on ollut täysin kuvitteellinen jo kaksikymmentä vuotta, siitä lähtien kun assistentin tointen asema "jatkokoulutuspaikkoina" lopullisesti romahti. Laitoksemme jatko-opinto-ohjeet ovat seuraavat: Ensin teet tutkimussuunnitelman, josta tiedät, että se ei toteudu. Kirjoitat sen pohjalta puoli tusinaa anomusta vuodessa Akatemialle ja säätiöille tietäen, että ensimmäisistä apurahoista on toivoa parin vuoden hakemusharjoittelun jälkeen. Sitä odotellessasi koetat harjoittaa jotakin, mistä on mahdollisimman vähän haittaa myöhemmin ehkä käynnistyvälle tutkimukselle. Ennen kaikkea: opettele kitkuttelemaan epämääräisten pikkurahojen ja työttömyysavustuksen turvin sekä muuttamaan suunnitelmaasi sen mukaan kun rahoitus loppuu.

Epämääräinen roikuskelu ei ole jatko-opiskelijoiden etuoikeus. Samassa kierteessä ovat yliopistoilla toimivat tutkijat — se joukko, josta joku keksi 80luvulla ottaa käyttöön nimityksen "tohtoritulppa". Ongelmana on yliopistojen järjetön virkarakenne: nimitys "professoritulppa" on paljon osuvampi. Tutkijoiden epämääräinen tilanne vaikeuttaa ennen muuta pitkäjänteistä, kriittistä perustutkimusta. Tutkimus, joka pyrkii arvioimaan kriittisesti omia lähtökohtiaan ja taustaolettamuksiaan, ei voi olla sidoksissa määräaikaiseen prỏjektirahoituk- 
seen. Tieteenhaarojen kritiikki on näivettymässä; väittääkö joku, että se ei ole yliopistojen keskeinen tehtävä?

Kuka juhlii, kun Suomen yliopisto juhlii?

Toki yliopistoissa on myös toiminnoissaan paisuvia ja menestyviä laitoksia: tiede- ja teknologiakyliä, jatkokoulutuskeskuksia, palvelulaitoksia. Uusia maakunnallisia yksiköitä suunnitellaan jatkuvasti: Vaasaan puuhataan yliopistoa. Tampereelle puuhataan luonnontieteellistä tiedekuntaa. (Tarmo Pukkilan kerrotaan - HS 30.3. - perustelleen: "Vaikka maassa on tarjolla varsin mittavasti luonnontieteellistä opetusta, se puuttuu kokonaan Pirkanmaalta." Kuolema!) Olennaista kuitenkin on, miten etenevät ne toiminnot, joita perinteisesti on pidetty yliopiston keskeisinä tehtävinä: korkeampi opetus ja vapaa tutkimus. Kysymys vaikuttaa vitsiltä, mikä on siihen ytimekäs vastaus?

Eräiden ajankohtaisten ongelmien ratkaisemiseksi riittäisi se, että "Suomen yliopisto" esittäisi yhtenäisenä subjektina joukon yksinkertaisia vaatimuksia. Esimerkiksi opetuksen perusteita jäytävässä tuntiopetusrahojen loppumisessa on kyse muutamasta miljoonasta markasta, mikä on merkitykseensä nähden täysin mitätön summa. Miksi yliopistot eivät yhdessä, koko henkilöstönsä tuella, vaadi tämän summan myöntämistä? Haluaisin nähdä punakynän, joka vetäisi määrärahan yli, jos sitä julkisesti perättäisiin. Sama pätee jatko-opintojen rahoitukseen, yliopistojen virkarakenteeseen ja pitkäjänteisen tutkimuksen mahdollisuuksiin. Siis korkeamman opetuksen ja vapaan tutkimuksen perustaviin edellytyksiin, joiden puutteessa yliopistot tällä hetkellä näivettyvät.

Mutta juuri yhtenäisen subjektin luominen on nykyiselle yliopistohallinnolle myrkkyä. Helsingissä sen estävät omaan jakkaraansa takertuvat autoritäärit. Muualla on vakiintunut perinne hoitaa asiat hallintoviraston ja ministeriön keskinäisin luottamuksellisin neuvotteluin, ja lisäksi painolastina ovat maakunnalliset intressit. Kaikkialla toteutuu kukon ja tunkion dialektiikka.

Kierrymme yliopistojen hallintoon. Yliopiston hallinnon mielekkäät mittapuut ovat aivan muita kuin organisaation muodollinen tehokkuus. Onnistunutta hallintoa olisi, että yliopistoväelle syntyisi edellytyksiä hahmottaa yhdessä ongelmia ja ratkaista niitä omissa eriytyvissä työympäristöissään. Tätä tukevat menettelyt ja keskustelutavat puuttuvat, koska mahdollisuudet vaikuttaa päätöksiin ja tulevaan kehitykseen puuttuvat. Helsingin yliopiston vanhan hallinnon vastaus on täysin yksiselitteinen: tärkeintä on valtarakenteiden suojaaminen, muulla ei väliä. Merkkivuoden juhlinnan tulos on luultavasti symbolisen pääoman kasautuminen konservatiivisen eliitin tueksi, siis negatiivinen. - Mutta ehkä tämä on ollut koko juhlahumun eräs tavoitekin?

Vyyhden taustana on tietenkin se, mitä yliopistojen ja tieteen yhteiskunnallisessa asemassa tapahtuu todella. Tätä ei tosiasiassa tiedä kukaan. Olemme jo tottuneet ministeriön voimistuvaan hallinnointiin sekä kehittämisohjelmien ja mietintöjen iskusanoihin (yliopistojen tavoitteellinen johtaminen; yliopistojen ja yhteiskunnan lähentäminen; jatkokoulutuksen tehostaminen; kansainvälisyys). Yhteyksien tiivistämistä liike-elämään todistavat yliopistojen rehtorit 
kilvan. Tämän kehityksen yhteys yliopistoväen käytännön työedellytyksiin on mitä epäselvin. On kuitenkin jo havaittu, että yliopistojen sivuorganisaatioiden paisuminen sekä yliopistojen muuttuminen palvelulaitoksiksi tuo yliopistoväelle uusia velvollisuuksia, jotka kaventavat mahdollisuuksia vapaaseen, kriittiseen tutkimukseen. - Tämän kertoi minulle matemaattiseen perustutkimukseen suuntautunut fyysikkoystäväni, jonka nykyinen yliopistollinen toimenkuva on ohjata paperikoneiden tuotekehittelyyn tähtääviä opinnäytteitä.

Kari Kantasalmi on toimittanut käyttöömme erinomaisen kokoelman yliopistokysymystä käsitteleviä perustekstejä, varhaisimpina kirjoittajinaan Kant, Fichte ja von Humboldt, viimeisimpinä Lepenies, Habermas, Lyotard ja Derrida sekä Lauri Mehtonen ja Juha Manninen (Yliopiston ajatusta etsimässä, Gaudeamus 1990). Kiintoisa piirre Kantasalmen kokoelmassa on, että 80-luvun yliopistoja arvioivat kannat menevät monilta osin ristiin. Yliopistot ovat murroksen alaisina, mutta missään ei ole valmista vastausta kysymykseen, miten yliopiston sivistyksen ja kriittisyyden ihanteita kyetään pitämään yllä.

Jürgen Habermas soveltaa kokoelmaan sisältyvässä esseessään moderniin yhteiskuntaan luonnehdintoja "vakiintumaton" ja "esikuvaton". Ehkä tämä on yksi yliopistokysymyksen ytimistä. Vain pieni osa siitä, mitä tapahtuu ja mikä näyttää väistämättömältä, on tosiasiassa väistämätöntä. Juuri nyt suomalaisen yliopiston hallinnollinen ohjaus ja markkinoituminen ovat vallitsevia kehityssuuntia, ja vapaan, kriittisen opetuksen ja tutkimuksen edellytykset kaventuvat. Juuri nyt näyttää siltä, että yliopistoväellä ei ole kehitykseen mitään sananvaltaa. Meidän on kuitenkin vältyttävä sortumasta itsensä toteuttaviin ennusteisiin.

Tietysti lähtökohdaksi on hyväksyttävä, että suomalaiseen yliopistoon on jo syntynyt pysyviä rakenteita jotka asettavat mahdollisille maailmoille rajoja. Yliopistomme on hajautunut ympäri maakuntia tavalla, joka herättää ulkomaalaisissa vieraissa kauhunsekaista hämmennystä. Sivuorganisaatiot ovat tulleet, ja ne pysyvät. Yksi johtopäätös on, että yliopiston on otettava entistä enemmän kriittistä etäisyyttä myös itseensä. Tämä korostaa yliopistoväen keskinäisen keskustelun merkitystä; ja jotta sille olisi todellisia edellytyksiä, vapaan, kriittisen opetuksen ja tutkimuksen perusehdot on turvattava. Tälle vaatimukselle ei ole tarvis keksiä välineellisiä perusteluja. Kansakunnan sivistyksen ja kulttuurin edistymisen kannalta korkeampi opetus ja vapaa tutkimus ovat samanlaisessa asemassa kuin taide: jos työskentelyedellytykset turvataan, töitä tehdään. 